\title{
ALEXANDER I OF YUGOSLAVIA AND THE METAMORPHOSIS OF HIS PORTRAYAL IN LEADING SLOVENIAN NEWSPAPERS
}

\section{SARA ŠPELEC}

This article presents how the portrayal of Alexander I of Yugoslavia in leading Slovenian newspapers changed during the years of his reign; from 1918, when he became the regent, and then three years later king, of the Kingdom of Serbs, Croats, and Slovenes, up to his introduction of a personal dictatorship in 1929 and ultimately his assassination in Marseille in 1934.

Keywords: Alexander I of Yugoslavia, newspapers, imagined communities, imagined traditions, holidays, censorship, hero, celebrity, discursive construction of national identity
Članek predstavi, kako so osrednji slovenski časopisi prikazovalijugoslovanskega kralja Aleksandra I. Karadordevića. Avtorica analizira, kako se je njegova medijska podoba spremenila v obdobju njegovega vladanja, in sicer od leta 1918, ko je postal regent, ter tri leta zatem kralj Kraljevine Srbov, Hrvatov in Slovencev, do uvedbe diktature leta 1929 in atentata $v$ Marseillu leta 1934.

Ključne besede: Aleksander I. Karadordević, časopisi, zamišljene skupnosti, imaginarne tradicije, prazniki, cenzura, junak, slavna oseba, diskurzivne konstrukcije nacionalne identitete

\section{INTRODUCTION}

This article presents how the portrayal of Alexander I of Yugoslavia in leading Slovenian newspapers changed during the years of his reign; from 1918, when he became the regent, and then three years later king, of the Kingdom of Serbs, Croats, and Slovenes, up to his introduction of a personal dictatorship in 1929 and ultimately his assassination in Marseille in 1934. The article concentrates on the predominant discourse in reports on the kingdom's

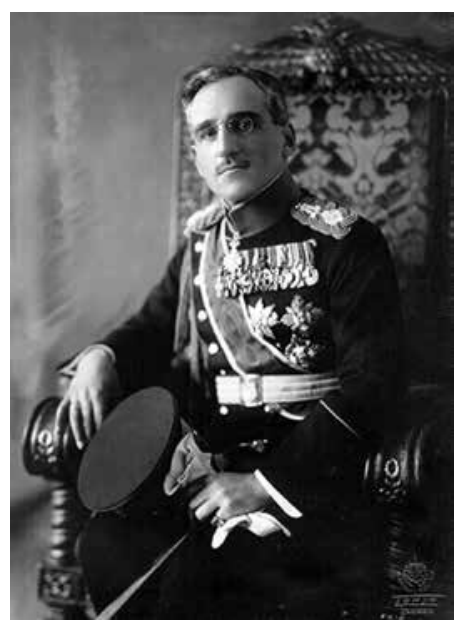

Figure 1: King Alexander I of Yugoslavia. Wikipedia. turning points and events that were of great public and national importance, such as the kingdom's founding, elections, and national holidays; the king's relationship with the Slovenian people, his marriage and the birth of his children; the assassination of Stjepan Radić; the beginning of Alexander's dictatorship; and, finally, his own assassination. On these occasions, Alexander's significance had to be retold, explained, and justified, which means he was not only portrayed as a war hero and a great man, but also a celebrity created by the media. The article also presents the concept of the nation as an imagined community, its imagined traditions and holidays, and the way they were presented in daily newspapers - initially in the Kingdom of Serbs, Croats, and Slovenes and later on in the Kingdom of Yugoslavia. 


\section{IMAGINED WORLDS (NEWSPAPERS, TRADITIONS, ETC.)}

Benedict Anderson writes that "the newspaper is merely an 'extreme form' of the book, a book sold on a colossal scale, but of ephemeral popularity." He thinks that newspapers could be called "one-day best-sellers" and that "the obsolescence of the newspaper on the morrow of its printing . . . creates this extraordinary mass ceremony: the almost precisely simultaneous consumption ('imagining') of the newspaper-as-fiction" (2006: 34-35). Newspaper consumption is usually reserved for the mornings or evenings, and Hegel felt it served "as a substitute for morning prayers" (Anderson 2006: 35). Although this ceremony is performed in silent privacy, readers are aware of the fact that there are thousands of others doing exactly the same thing at exactly the same time; that is, reading the same edition of the same newspaper. Although readers are obviously aware of each other's existence, their identity remains an enigma, but when they observe exact replicas of their own newspaper consumed in different places, they are reassured "that the imagined world is visibly rooted in everyday life." He concludes that "fiction seeps quietly and continuously into reality, creating that remarkable confidence of community in anonymity which is the hallmark of modern nations" (Anderson 2006: 36). For the same reason, Anderson considers the nation to be "an imagined political community" whose members "will never know most of their fellow-members, meet them, or even hear of them" (Anderson 2006: 6).

Eric Hobsbawm, on the other hand, writes about "invented traditions," which he defines as "a set of practices, normally governed by overtly or tacitly accepted rules and of a ritual or symbolic nature ... which automatically implies continuity with the past" (1998: 1). It should thus come as no surprise that he considers the nation to be a "recent historical innovation" whose "associated phenomena" are nationalism, national symbols, and so on (1998: 13).

Members of imagined communities celebrate their holidays so that they do not forget their collective past, which enables them not only to understand their present, but also their future. They are proud of important historical events and personalities, who are not only objects of worship, but symbols for which they are prepared to die (Jezernik 2013a).

The most important form of remembering the collective past of a nation is state holidays. They present a symbolic unity of the most important events and personalities, which are celebrated with mass gatherings, hanging out flags, and playing the anthem (Jezernik 2013b). 


\section{STATE HOLIDAYS IN ALEXANDER'S YUGOSLAVIA ${ }^{1}$}

In 1919 the internal affairs minister of the Kingdom of Serbs, Croats, and Slovenes announced three state holidays: St. Vitus's Day on June 28th (or June 15th according to the Julian calendar), the memorial day to Serbian holy martyrs; King Peter's Day on June 12th (the birthday of King Peter I); and Unification Day on December 1st (the unification of the Serbs, Croats, and Slovenians). St. Vitus's Day, the most emotional holiday in the history of the Serbs, who lost the Battle of Kosovo on the very same day in 1389, played the most important role in the collective memory "of three nations." The day had an important impact on Serbian and later Yugoslav history. Gavrilo Princip's assassination of Archduke Franz Ferdinand on June 28th, 1914 led to the declaration of war, followed in 1919 by the signing of the Treaty of Versailles and in 1921 the adoption of the St. Vitus's Day Constitution. When King Alexander introduced his personal dictatorship in 1929, the new list of state holidays included only his birthday (December 16th) and Unification Day, but this does not mean that St. Vitus's Day was forgotten. Commemorations in memory of the war victims were still held and the flags were hung from the state buildings, town halls, and so on. St. Vitus's Day was supposed to unify "the nation” of Serbs, Croats, and Slovenes, but unfortunately it became, as Božidar Jezernik wrote, "a stumbling-block to their coexistence" (Jezernik 2013b: 40). "Three tribes of the same nation" that had never before lived in the same state and whose national awakening had taken place in nineteenth century could not be "reunited" on the basis of Serbian mythology. St. Vitus's Day is in fact a holiday of premodern society, when individuals sacrificed themselves for the community, and its mythology does not belong in the modern world (Jezernik 2013b).

\section{YUGOSLAV AND SLOVENIAN NEWSPAPERS BETWEEN THE TWO WORLD WARS}

The Yugoslav political press was more or less regionally oriented, which means that particular newspapers did not reach wider circles of readers, but only smaller ethnic or religious groups. Party leaders had often worked as journalists or even editors of their newspapers and thus the monikers "Korošec's Slovenec" or "Žerjav's Jutro" came as no surprise. ${ }^{2}$ The most important thing was therefore the political orientation of the newspaper and the current political climate. During the parliamentary period (1919-1929), the daily and political press went hand-in-hand, and so it is very difficult to separate one from another

1 From the beginning, Yugoslavia was the colloquial name for the Kingdom of Serbs, Croats, and Slovenes and, although the Kingdom of Yugoslavia was established only in 1929, I sometimes use the term Yugoslavia for both periods.

2 Anton Korošec was the leader of the Slovenian People's Party and Gregor Žerjav the leader of the Slovenian liberals. 
and almost impossible to talk about an "independent press." Political elites nevertheless continued to spread the myth of Yugoslav parliamentarism, proving that their role model was the West. Moreover, although some newspapers, especially larger ones, declared political independence, it was not particularly difficult to recognize their political preferences. The list includes Slovenian newspapers, such as Slovenec (The Slovenian), with a Catholic orientation, and Slovenski narod (The Slovenian Nation) and Jutro (Morning), both with a liberal orientation. Before January 6th, 1929, when Alexander introduced his personal dictatorship, the Kingdom of Serbs, Croats, and Slovenes had 703 journals and newspapers, of which 113 were published in the Slovenian part of the kingdom. There were thirty-five daily newspapers in the kingdom (the three mentioned above were Slovenian): sixteen were independent, twelve were political, and two were official gazettes (Amon 1996).

After the January 6th Dictatorship was declared, all political press was forbidden and all newspapers were censored. The political press was thus recast as informational, religious, or literary press, professional journals, and so on (Amon 1996).

\section{CENSORSHIP}

When the former minister Milan Stojadinović returned to Belgrade on October 9th, 1934, a policeman approached him, whispering: "The king is dead, he was assassinated in Marseilles" (Gašparič 2010: 89). Stojadinović could not believe it, so he went directly to the store in order to buy the latest edition of the Belgrade newspaper Pravda (Justice), but all he could find in its pages was a detailed report of Alexander's reception at the French port: the enthusiastic crowd, the speeches, the ceremony, and so on. Naturally, none of these events had actually taken place, but considering that the Yugoslav newspapers were under the censor's eye it is not hard to guess that the news for the Belgrade newspaper had been selected and arranged the day before. After the January 6th Dictatorship declaration, a new press law came into force. It was not actually new because it was an adjustment to the old law from 1925, which still guaranteed freedom of the press (which in reality did not exist) and had not yet introduced pre-censorship of the national and foreign press. ${ }^{3}$ The censors at the notorious Central Press Bureau included people known for being poor students in high school or for not even finishing elementary school, which makes their censorship even more absurd (Gašparič 2010). In 1919, the press agency Avala was established in the kingdom by a French journalist, Albert Moysset, who was recognized as a spy in 1927. After that the agency became a burden for the state budget and two years later it was transformed into a joint-stock company. Its major stockholder became the Kingdom of Yugoslavia, which held 95\% of the stock (Amon 1996). Before the introduction of the

3 Censorship in the Slovenian press was certainly not Alexander's "invention." It was first introduced in the period of enlightened absolutism, the era of Maria Theresa (Polajnar \& Zajc 2012: 229). 
dictatorship, the newspapers were either owned or influenced by various political parties whose opinion of the king was connected to their political orientation. However, when the political parties were abolished, the king's birthday made the front page of every daily newspaper (Nežmah 2012).

Ernst Toller, a German writer of Jewish descent, wrote a biography that contains the following anecdote. One day he asked his mother if the emperor really "had to go to the toilet." She told him that he would have to go to prison if somebody heard him, and so her answer was no (Polajnar \& Zajc 2012: 22).

We are not always allowed to say everything and have no other choice but to conceal some information. Censorship is thus related to fear and could be compared to Michel Foucault's definition of discourse, which is "really no more than the repressive presence of what it does not say; and this 'not-said' is a hollow that undermines from within all that is said" (Foucault 2001: 28). We should "rediscover the silent murmuring, the inexhaustible speech that animates from within the voice that one hears, re-establish the tiny, invisible text that runs between and sometimes collides with them" (Foucault 2001: 31).

\section{THE BIRTH OF CELEBRITIES}

After 1929, the daily press went through some changes. Editors were no longer members of political parties, but well-organized, pragmatic individuals with a broader perspective. Although political articles were replaced by the news, which was now on the front pages, it was difficult to overlook editors' political orientations. The editorials were overshadowed by the news and were "hidden" on the internal pages and a new type of reader was born: the semi-literate reader interested only in comics. Newspapers were full of advertisements, recipes, and fashion tips, and they became "woman-friendly." The feuilleton was replaced with reportage and later with photojournalism, which means that the text was overshadowed by photographs and illustrations. Movie stars and their scandalous lives became much more important than theater reviews, which were replaced by gossip, leading to an obsession with celebrities (Amon 1996).

Although Alexander was a war hero and a king (the last and the most important form of heroism, according to Thomas Carlyle), he was also a public person that lived in a time when heroes were overshadowed by celebrities. Daniel J. Boorstin wrote that since the graphic revolution, which he feels took place in the nineteenth and twentieth centuries, "our age has produced a new kind of eminence[:] a person who is known for his well-knownness [emphasis added]"; in other words, "a celebrity" (1992: 57). Joseph Campbell discovered that important myths from all around the world share a fundamental structure, which he called the monomyth, summarized in famous quote: "A hero ventures forth from the world of common day into a region of supernatural wonder: fabulous forces are there encountered and a decisive victory is won: the hero comes back from this 
mysterious adventure with the power to bestow boons on his fellow man" (2004: 28). A celebrity is not defined by his or her qualities, but rather by the lack of them, and is therefore "a human pseudo-event," which replaced the traditional hero (Boorstin 1992: 61). The democracy of pseudo-events enables everybody to become a celebrity, but they must first get into the news and stay there. Whereas the hero was a self-made man that was distinguished by his achievements, a celebrity is only a big name created by the media. Heroic figures were once distinguished by their scorn for publicity and their only reward was their achievements. As time went by they became increasingly heroic, and are therefore considered to be ancients, whereas celebrities are nothing more than the subject of gossip, public opinion, and newspapers, and are always contemporaries. They suffer from idiosyncrasy and, due to their vividness and individuality, are not suitable material for symmetrical Greek statues. They are destroyed by the publicity that created them in the first place (Boorstin 1992).

\section{CHARACTERISTICS OF THE NEWSPAPERS ANALYZED}

This article concentrates mostly on the leading Slovenian newspapers Slovenec, Slovenski narod, and Jutro, but also includes the newspaper Slovenski gospodar (Slovenian Homeowner) and the youth magazine Sokolic (Young Hawk).

Slovenski narod was published from 1868 to 1945 in Ljubljana, first as a weekly newspaper and from 1873 onwards as a daily newspaper with a liberal orientation. It is a historical source of the old Slovenian liberal tradition and it was in favor of the regime from its beginnings. Slovenec was a conservative daily newspaper published from 1873 to 1945 in Ljubljana. It was the official gazette of the Slovenian People's Party and therefore an important source of conservative orientation. It was strongly against state centralism and the St. Vitus's Day Constitution adopted in 1921. Its attitude towards the regime more or less depended on the current political position of the party.

Jutro was a liberal daily newspaper, published from 1920 to 1945 in Ljubljana, and it presents a useful source of younger liberal orientation. Its attitude towards the regime was very similar to that of Slovenski narod, although its favoritism is more obvious from time to time.

Slovenski gospodar was a conservative weekly newspaper published from 1867 to 1941 in Maribor. It presents a useful source for a new, "anti-German” Slovenian identity in 1918.

Sokolič was a youth magazine with a liberal orientation published from 1919 to 1938 in Ljubljana. After Alexander's assassination, it divided his life according to Campbell's later monomyth and is therefore essential for this article. 


\section{DISCURSIVE CONSTRUCTION OF NATIONAL IDENTITY}

My analysis of Alexander's portrayal is based mostly on the discursive construction of national identity. A study was developed by Rudolf de Cillia, Martin Reisigl, and Ruth Wodak, who adopted Anderson's thesis that nations are mental constructs or imagined political communities. They believe that the idea of a specific national community becomes reality through figurative political, intellectual, and media discourse, and that national identity is, as Pierre Bourdieu put it, a sort of habitus, which is a complex of common ideas and concepts or perception schemes. National identity is furthermore closely connected with construction of difference or distinctiveness and uniqueness. The method does not assume the existence of a one-and-only national identity, but of different identities that are discursively constructed according to context. Media portrayals are nevertheless related to nations and national identities in a certain way. This study combines various interdisciplinary, methodological, and source-specific approaches, which makes it possible to explore the discursive construction of national identity from historical, sociopolitical, and linguistic perspectives. The materials analyzed included political speeches, newspaper articles, posters, interviews, and so on (de Cillia, Reisigl, \& Wodak 1999).

Focusing on the discursive construction of the Austrian identity and nation, the study distinguishes between three interrelated dimensions: contents, strategies, and linguistic means and forms of realization. The contents are divided into five semantic macroareas, but I am particularly interested in the idea of a "Homo yugoslavicus" and a "Homo externus," the narrative of a collective political history, and the discursive construction of collective present and future. The first macro-area also includes an assumed "nation" mentality with "national" dispositions or habits and different aspects of the biographical genesis of national identity or nationality, including destiny, chance, and origin. The second area contains "myths of genesis and origin, mythical figures, times of flourishing and prosperity, decline, defeat and crisis" (de Cillia, Reisigl, \& Wodak 1999: 158-159). The second principal element of discursive constructions is strategy; in other words, a plan of action with automatic or conscious realizations that exist at different levels in our minds. I am interested in constructive strategies accompanied by linguistic devices that help establish a particular national identity and thus enable identification and solidarity with the "we-group" and at the same time marginalization of "others." The linguistic analysis is based on lexical units, argumentation schemes, and syntactic means that are used to express unity, sameness, difference, singularity, autonomy, heteronomy, and so on. The most important is the use of the personal pronoun we and all its possessive forms. The sameness between people is created by the use of metonymy, synecdoche, and personification, especially when constructive strategies are used. By using metonymies, speakers dissolve individuals, who are kept in the semantic background. There are two kinds of synecdoche: the particularizing synecdoche (pars pro toto or a collective singular), such as "the foreigner," and the generalizing synecdoche (totum pro parte), such as 
"Yugoslavia is the winner." Particularizing synecdoches often generalize and essentialize stereotypes that address a group of persons, whereas personifications give human form to abstract entities (anthropomorphization), such as "Yugoslavia's mentality" (de Cillia, Reisigl, \& Wodak 1999).

\section{ALEXANDER'S PORTRAYAL IN SLOVENIAN NEWSPAPERS}

On important dates under Alexander's regency, reign, and dictatorship from 1918 to $1934,{ }^{4}$ newspapers consolidated his position directly and indirectly through six different categories: myths of genesis and origin, expression of sameness through difference (identity per negationem), Alexander among the Slovenian people (the identificational category), poems, anecdotes, and Alexander as a hero/celebrity. Before the January 6th Dictatorship, disapproval of his regime was expressed by either outspoken or disguised critique and after that only disguised.

There is limited space for examples, so I first to summarize how the newspapers responded to important anniversaries through the years. Slovenski narod and Jutro were in favor of the regime from the beginning, which means that Unification Day, King Alexander's birthday, and St. Vitus's Day were always considered events of great importance. Nevertheless, the first critical attitude towards the regime appeared on anniversaries of Unification Day in the mid-1920s — at first only as a disguised critique, but later also outspoken after Stjepan Radić, the most important Croatian politician, was shot by the Serbian nationalist Puniša Račić in the Parliament in 1928. After the January 6th Dictatorship, anniversaries of Unification Day and the king's birthdays were celebrated with a photograph of the heroic king (usually on the front page), who in 1929 took the future into his hands in order to provide a better one. Slovenec, on the other hand, did not try to hide its disapproval of the regime after the adoption of the St. Vitus's Day Constitution in 1921. Anniversaries of Unification Day were sometimes completely ignored and St. Vitus's Day was described as a day of little importance that brought bad luck. After Radićs death in 1928, Anton Korošec became prime minister and the newspaper's point of view dramatically changed. Even Slovenski narod and Slovenec took a critical stance, whereas Jutro defended the regime. After the declaration of dictatorship, the political parties were forced to stop their activities and relations between the royal regime and the Slovenian People's Party gradually worsened. Due to censorship the king's birthday made the front pages, but the poems under his photograph were dedicated not only to his heroic figure, but also to "homeless Slovenians" that lived in Austria and Italy, which can be considered a disguised critique of the regime (Jutro, Slovenec, and Slovenski narod 1918-1933).

4 The list of important dates is in the table below. 


\begin{tabular}{|l|l|}
\hline \multicolumn{2}{|c|}{$\begin{array}{c}\text { Important dates in the Kingdom of Serbs, Croats, and Slovenes and in the Kingdom of } \\
\text { Yugoslavia, or Alexander's calendar in leading Slovenian newspapers }\end{array}$} \\
\hline St. Vitus's Day & June 28th, 1389 (1914, 1919) \\
\hline Unification Day & December 1st, 1918 \\
\hline Alexander's birthday & December 16th, 18885 \\
\hline Peter I's birthday & July 12th, 1844 \\
\hline Alexander's first visit to Slovenia & June 26th, 1920 \\
\hline Adoption of the St. Vitus's Day Constitution & June 28th, 1921 \\
\hline Alexander becomes king & August 17th, 1921 \\
\hline Alexander's wedding & June 8th, 1922 \\
\hline The birth of Crown Prince Peter II & September 6th, 1923 \\
\hline The birth of Prince Tomislav & January 19th, 1928 \\
\hline Shooting in the Parliament & June 20th, 1928 \\
\hline Establishment of the January 6th Dictatorship & January 6th, 1929 \\
\hline The birth of Prince Andrej & June 28th, 1929 \\
\hline Establishment of the Kingdom of Yugoslavia & October 3rd, 1929 \\
\hline Alexander decrees a new constitution & September 3rd, 1931 \\
\hline Alexander's assassination in Marseille & October 9th, 1934 \\
\hline
\end{tabular}

\section{I) MYTHS OF GENESIS AND ORIGIN}

Newspapers indirectly consolidated the king's position in their texts or by quoting his speech. Indirect consolidation of his position in writing was obvious after the unification of the Serbs, Croats, and Slovenians. On December 1st, 1918, the newspapers were full of articles about the country's shared past and common descent. One could, inter alia, read about the cruel separation of the nation's "three tribes" dating back to the sixth century and the loss of a common language that had been widespread from the Alps to the Black, Aegean, and Adriatic seas.

"One thousand, two hundred and a thousand or perhaps even more years have passed since the sun of freedom shone upon us. /.../ Our ancestors lived not only free, but as true democrats" and were thus the only anachronistic exception of the feudal world. The state symbol was the "inauguration of Carinthian dukes at Zollfeld," which was against "European state regulation of that time," so "it was bound to fall apart." And that is how "the Slovenian part of the Yugoslav nation lost its independence" (Slovenski narod 1918: 1).

After unification, Alexander said he promised to fulfil his duty "as a sovereign, and to continue the work of the most famous sons of our blood and religion, who bore our three names" that had begun under the reigns of his late grandfather Prince Alexander of Serbia and Prince Mihailo “so that our nation's hopes and dreams will come true” (Aleksander 1918: 1).

5 Newspapers reported that he was born on December 16th, whereas Serbian historian Branislav Gligorijevićs biography states that he was born on the 17th. 
In the same category, newspapers directly consolidated the king's position only in their texts. Newspapers taught that "the wheel of time began to turn and brought freedom not only to the Serbs, but also to their Slovenian and Croatian brothers." The ruler was "no autocrat," but "a crowned president of the republic" (M. P. 1918: 2).

Analysis of this content shows that the first category contains myths of genesis and origin (cruel separation of the three tribes of the nation in the sixth century), times of flourishing and prosperity ("years have passed since the sun of freedom shone upon us," our ancestors lived "as true democrats," the king remembers "the most famous sons of our blood and religion"), decline, defeat, and crisis (we were "the only anachronistic exception of the feudal world," so our state "was bound to fall apart" and "the Slovenian part of the Yugoslav nation lost its independence"); the idea of a "Homo yugoslavicus" (our ancestors were "democrats," "the only anachronistic exception of the feudal world"), a "Homo externus" (everybody else in a feudal world), the narrative of a collective political history (we were "free" and "true democrats"), and the discursive construction of the collective present and future (the king would continue the work begun "under the reign" of his "late grandfather" so that our "hopes and dreams will come true"; "the wheel of time began to turn and brought to us freedom"). ${ }^{6}$

Study of these linguistic means and forms of realization reveals that lexical units express unity, sameness, singularity, autonomy, and heteronomy, as seen in the passage above; "we" and all its possessive forms are used ("of our blood and religion," "our three names," "our nation," etc.), metonymies ("the sun of freedom shone upon us," we were "the only anachronistic exception," "the most famous sons of our blood and religion") and personification" ("the wheel of time began to turn and brought us freedom").

\section{II) EXPRESSION OF SAMENESS THROUGH DIFFERENCE (IDENTITY PER NEGATIONEM)} In this category newspapers consolidated the king's position indirectly only in their texts.

On November 23rd, 1918 Maribor was seized by Slovenian troops and the Germans were seen from then on as nothing but a savage tribe that wanted to prevent Yugoslav celebrations. "The Fritzes ${ }^{7}$ hoped that the rain and snow would prevent Sunday's celebration," but the sun decided to shine and celebrate "with our Yugoslav nation." And so the celebration ended without the usual German misbehavior "for we are a well-mannered nation and not some German savages" (Praznik 1918: 1).

Leskovec/An anonymous writer wrote that the Serbian nation had no nobility, privileges, or titles, and could not possibly be more democratic. He was convinced that Slovenian people were disgusting drunkards, whereas Serbian officers and Serbs in general are "without an exception teetotalers" and are sober even when they attend "the biggest celebrations."

6 Constructive strategies ("we" groups and, often, marginalization of "others") are essential in all categories (with the exception of anecdotes) and are not especially explored here.

7 "Fritz" is a pejorative term for "German" used during the First World War. 
The Karadjordjević dynasty in Serbia is considered as "an executor of national will" and "a symbol of national freedom and independence" (Leskovec 1918: 1).

In 1919, St. Vitus's Day was celebrated in Slovenia for the first time. Newspapers agreed that "South Kosovo is now revenged." It was "Serbian and therefore ours" and that is why not only Ljubljana, but "all inhabitants of our world" would celebrate "a fair St. Vitus's Day" (Slovenski narod 1919: 1).

Newspapers had been telling their readers that they were nothing but the remnants of defeated Austria and, because Serbia was among the winners, they must unite with the victorious nation of their blood. The Habsburgs had done nothing for them, but "Serbian people with the help of their king overcame all difficulties" and therefore "we welcome regent Alexander as our savior." The only solution was "unification under the victorious rule of the Serbian regent" (Slovenski gospodar 1918a: 1).

Analyzing this content reveals that the second category contains the idea of a "Homo yugoslavicus" ("we are a well-mannered nation and not some German savages," "all inhabitants of our world" would celebrate "a fair St. Vitus's Day"), a "Homo externus" ("the Fritzes hoped that the rain and snow would prevent Sunday's celebration," "the celebration ended without the usual German misbehavior") and the discursive construction of a collective present and future (our only solution is "unification under the victorious rule of the Serbian regent").

The analysis of linguistic means and forms of realization shows that lexical units express unity, sameness, singularity, autonomy, and heteronomy: "we" and all its possessive forms are used ("with our Yugoslav nation," "we are a well-mannered nation," "our world," "our blood," etc.), metonymies (Germans are "the Fritzes," Slovenians are "disgusting drunkards," Serbs are "without an exception teetotalers," we are nothing but "the remnants of defeated Austria," Alexander is "our savior," Serbs are "a nation of our blood"), synecdoches (the Karadjordjević dynasty—-meaning Peter I and Alexander-is "an executor of national will” and "a symbol of national freedom and independence," Yugoslavia is "our world," Serbia is the "winner"), and personification (Serbia is the "winner"). ${ }^{8}$

\section{III) ALEXANDER AMONG THE SLOVENIAN PEOPLE/IDENTIFICATIONAL CATEGORY}

In this category newspapers consolidated the king's position directly through a combination of quoting others' speech and texts, quoting only others' speech, a combination of his speech and their texts, and only their texts.

Using the speech of others and texts: When Alexander visited Ljubljana for the first time, on June 20th, 1920, a little girl approached him, saying: "Dear sovereign, our fate is in your hands." He was deeply moved, and so he "took her bouquet and kissed the little patriot on the forehead" (Slovenski narod 1920c: 2). 
Others' speech: Slovenec reported that the girl was a Slovenian from the coastal district, which was then a part of Italy, saying that they had been left not only without a homeland but also "without a father" (Slovenec 1920: 1).

The king's speech and text: He was especially fond of Upper Carniola, where he had a summer mansion. When he had to leave it for the first time, he said goodbye, using the following words: "I regret that I will have to leave this beautiful land and the strong, patriotic Slovenian nation and I really do hope that I will soon return and spend time among my dear Slovenians as often as I possibly can." Slovenski narod concluded that the second St. Vitus's Day turned out to be a "celebration of free men" and "an unprecedented national holiday" (Slovenski narod 1920a: 1).

Text: When his first son Peter was born, "we all felt that the baby was ours" and that through his veins ran the blood "of simple Slovenian, Croatian, and Serbian peasants," which meant that "we were now part of a royal family" (Jutro 1923: 1).

Analysis of this content shows that identificational category contains the idea of "a Homo yugoslavicus" and "a Homo externus" (a Slovenian girl, who lives in Italy, is left not only without a homeland but also "without a father," and so she considers Italians to be "Homo externus") and the discursive construction of a collective present and future (St. Vitus's Day turned out to be a "celebration of free men" and "an unprecedented national holiday," the girl said to Alexander: "Dear sovereign, our fate is in your hands," Alexander hoped to spend more time among his "dear Slovenians, as often as he possibly can”).

According to the study of linguistic means and forms of realization, this category consists mainly of lexical units that express unity, sameness, singularity, autonomy, and heteronomy: "we" and all its possessive forms are used ("our fate is in your hands," "they are without a homeland," Alexander is our "father," "my dear Slovenians," "the baby is ours," "we are part of a royal family"), metonymies (the girl is "a little patriot," Alexander is our "father," St. Vitus is a "celebration of free men" and "an unprecedented national holiday"), and synecdoches ("our fate is in your hands," "patriotic Slovenian nation," through Peter II's veins runs the blood of "Slovenian, Croatian, and Serbian peasants," which means we are closely related and he is therefore a representative of the people).

\section{IV) POEMS}

Newspapers consolidated his position either directly or indirectly using poetry. Alexander was considered to be the first national ruler to acknowledge "Slovenianness." Therefore his position was consolidated directly in Slovenian newspapers. This is obvious from the following fragment: "Oh, master, you are ours! You came / In spirit, blood, and soul the same, / Our homeland is now safe and free / And you're the ruler of all three" (Funtek 1920: 1). When he was assassinated in 1934, the following poem by Oton Župančič was engraved on the urn in golden letters: 
There was a custom once

To give a precious thing

To the prince, who will the gift

To his last journey bring.

We give to thee what we love best: our soil is in the urn

Your fate was ours; it's our concern

How peacefully you'll rest (Župančič 1934: 3).

King Alexander's position was also indirectly approved through poems. After the unification, newspapers agreed that the kingdom had become one nation (Yugoslavia) and some writers expressed their enthusiasm with poems. The tricolor was now "as blue as the sky, as red as blood, and as white as snow" and "we're no longer one, but three / all brothers: Serbs, Croats, Slovenes. / O, mother / glorified art thou” (Savinjska 1918: 2).

Content analysis shows that the category of poems consists of the idea of a "Homo yugoslavicus" ("we're no longer one, but three," that Alexander came "in spirit, blood, and soul the same") and of the discursive construction of the collective present and future (we are now "three," "our homeland is now safe and free," "your fate was ours; it's our concern how peacefully you'll rest," which meant that he would always be "ours").

Study of these linguistic means and forms of realization reveals that the identificational category consists of lexical units that express unity, sameness, singularity, and autonomy: "we" and all its possessive forms are used ("we're no longer one," "Oh, master, you are ours!," "our homeland," "your fate was ours"), metonymies (the flag is equal to "blue, red, and white," Serbs, Croats, and Slovenians are "brothers," Alexander is "our master" and a "ruler," a "prince" and is referred to as "thee," which means he is respected and loved at the same time, he must "rest peacefully," "we give to thee, what we love best: our soil is in the urn"; in other words, we are with you), synecdoche (you have our "spirit, blood, and soul"), and personification (the homeland is a "glorified mother").

\section{V) ANECDOTES}

When newspapers anticipated his arrival or celebrated days of national importance and the king's national and personal achievements, he began to appear in anecdotes. These did not highlight his great achievements, but rather his human qualities, thereby indirectly consolidating his reign.

\section{"Alexander's First Visit to Slovenian Soil"}

The first evidence of his presence in the Slovenian part of the kingdom goes back to 1909 . He came to Rogaška Slatina "on a simple Croatian farm wagon," accompanied by his adjutant. He did not reveal his true identity, and so he signed the guestbook with the name "Monsieur le Comte d'Avala mit Kammerdiener aus Belgrad." (Slovenski narod 1920b: 3) 


\section{"The Crown Prince Will Be the Last to Leave"}

After the Albanian Golgotha in 1915, the Serbian army retreated to Shkodër. Although Alexander was seriously ill, his main concern was his soldiers. He stood on the shore waiting for rescue ships to arrive and, when they finally came, the duty officer approached him, saying: "Your royal highness, you can go onboard." Alexander smiled bitterly, replying that "my turn will come when all the soldiers and refugees have been rescued," for "I am the last to leave our homeland" (Slovenski narod 1921b: 2).

\section{"The Godfather" (Serb. Šišani kum).}

There are two types of godfather in Serbia: the person that sponsors a child's baptism, and the first person to cut the child's hair. In 1920 Alexander went to the source of the Bosna River without an escort and stopped at a farmhouse on the way. The householder invited him inside, offered him food and drink, and enjoyed a pleasant conversation with the regent. When the householder's grandson came into the room, Alexander asked him: "Do you want me to be your godfather?" While the women were weeping with joy, Alexander "took the scissors and, according to the old custom," cut his hair "all over his neck" (Slovenski narod 1921c: 2-3).

Study of these linguistic means and forms of realization shows that Alexander's humanity is described by using metonymies; in other words, he is not called by name, but defined by his character. He is not just an ordinary crown prince and regent, but a person with whom people can identify. Two questions are essential here: who did something and how did he do it? In the first anecdote he is "Monsieur le Comte d'Avala," who came "on a simple Croatian farm wagon," which means his main characteristic is modesty. In the second anecdote he is portrayed as someone that is "the last to leave," who waits "for rescue ships to arrive" and "smiled bitterly," when he was offered the chance to go onboard and leave his soldiers behind. He is thus an unselfish man, willing to make sacrifices. In the last anecdote he is a godfather, who cuts a child's hair and enjoys "a pleasant conversation" with simple peasants, which means he is a warm and friendly person.

\section{VI) ALEXANDER AS A HERO/CELEBRITY}

In leading liberal newspapers, King Alexander's popularity increased from 1921 and he was thereafter considered to be a hero or, adopting Boorstin's description, a celebrity. One could therefore "sympathize with any political party," be it communist or clerical, "Serb, Croat, Slovenian, German, or Turk," but if he was a person of common sense and firm character he was able to see that Alexander truly had "a great, pure spirit" (Slovenski narod 1921a: 3). When he decreed a new constitution in 1931, Jutro reported how grateful the people were for his efforts and for everything he had done for Yugoslavia, "especially after the January 6th Dictatorship, when he took on the great responsibility for our future" (Jutro 1931: 2).

After his assassination in Marseilles in 1934, his figure became even more heroic, accompanied by his purported last words "Take care of Yugoslavia!.” "Our great king 
Alexander I died on October 9th at $4 \mathrm{pm}$ as a victim of a vile assassination" and his last words were to be taken very seriously. "It was the death of a hero on the battlefield," for he was "a great hero that liberated us," "our king Matthias, the prophecy of our folksongs" and "we are now poor orphans whose beloved father was killed by a villain." Although "the man-leader-nation" was dead, his homeland was not (Jutro 1934: 2).

His life path can be divided into the following stages, according to Campbell's monomyth:

Early youth-heir to the throne-winner of the Balkan wars-the hope for enslaved Yugoslavs-regent and commander-in-chief-the king-peacemaker. (Sokolič 1934)

At first he was just the quiet brother of an heir to the throne, who was studying abroad and was forced to come back after George's abdication. He then ventured "into a region of supernatural wonder"; in other words, he went to war. He won important battles in the Balkan wars and after he survived the Albanian Golgotha and won the First World War, he became a great hero, who not only returned home "with the power to bestow boons on his fellow man," but created a new one for Serbs and their enslaved brothers (Campbell 2004: 28).

Considering others' comments, the statement by Ignacij Nadrah is probably most interesting. On the occasion of the king's funeral, the provost said: "We are now orphans, we have lost our father" and "if we Christians today mourn our king, it is not because we are hypocrites ... we are only trying to fulfill the fourth commandment" (Slovenski narod 1934: 3).

In his speeches, King Alexander stressed the importance of the relationship between the people and himself. When in 1929 he introduced a personal dictatorhip, he addressed the people in the following manner: "To my beloved nation! To all Serbs, Croats, and Slovenians! The time has come when no one will ever come between the nation and its king." Parliamentarism had always been his ideal, but it had now come to an end "because political parties with their blind passion began to abuse the system" and it became impossible to work under these conditions. Not only that, but also "unfortunate events that took place in the parliament" are the reason for national distrust.9 "My duty is to do whatever it takes to protect our state and national unity" and therefore "the Constitution of Serbs, Croats, and Slovenes will be abolished" (Aleksander 1929: 1).

According to the content analysis, this category consists of the discursive construction of a collective present and future (after the January 6th Dictatorship "he took on the great responsibility for our future"; his dying words were said to be "Take care of Yugoslavia"; Alexander liberated the people and was "the hope for enslaved Yugoslavs"; although "the man-leader-nation is dead," his homeland was not; the king abolished "the Constitution of the Serbs, Croats, and Slovenes" to protect "national unity").

\footnotetext{
9 This refers to the murder of Stjepan Radić.
} 
Study of these linguistic means and forms of realization shows that they consist of lexical units that express unity, sameness, singularity, and autonomy: "we" and all its possessive forms are used ("he took on the great responsibility for our future," "our great king Alexander I," "we are orphans," Alexander said he would "protect our state"), metonymies (Alexander is a person of "a great, pure spirit," "a hero on the battlefield," "a great hero," "our king Matthias," "the prophecy of our folksongs," "our father," "the king-peacemaker," we are "poor orphans," "we Christians today mourn," "unfortunate events" are the reason for national distrust), synecdoches (one could be a communist, clerical, "Serb, Croat, Slovenian, German, or Turk" - if he had common sense, he would have admiration for the king, for he had done so much "for Yugoslavia," "take care of Yugoslavia," "the man-leader-nation is dead," but his homeland is not, the king addressed his "beloved nation," by which he meant the Serbs, Croats, and Slovenes, "no one will ever come between the nation and its king") and personification ("take care of Yugoslavia").

\section{VII) CRITIQUE OF THE REGIME}

Outspoken and disguised critiques were present only in texts.

The first type, the outspoken critique, was expressed in Slovenec; it was the only leading newspaper that had a critical attitude towards unification. It wrote in favor of the republic, for "thrones are shaking and falling everywhere" and the country was surrounded only by republics. They would no longer "worship monarchs, who are believed to be earthly gods, grovel before them, or flatter them." And although "we love the Serbs and hold them in high esteem, there is no reason to despise ourselves." It would be wonderful if the unification were possible, but "common sense tells us" that "this process takes a long time" (Slovenec 1918: 1).

The St. Vitus's Day Constitution was adopted on June 28th, 1921. The Slovenian clerical party was among those that strongly opposed the state centralism legalized by the constitution, a fact they had no intention of concealing. "The fact that we have a constitution should be a happy event," if only we were not "strongly against it." But "the regent swore on it," so we have no choice but to adopt it, "although it is against our will." Nevertheless, "the revision of the reactionary, centralist constitution will from now on be a goal of every anti-centralist party" (Slovenec 1921: 1).

On St. Vitus's Day 1928, just a few days after the shooting in the parliament, Jutro wrote that the country had found itself in a "disgusting situation" and therefore problems must "immediately be solved," otherwise their unity would be in serious danger. Although most Serbs were "honest and devoted to freedom," they must get rid of these "vile and violent individuals," for only an "honest Serbian nation will be able" to overcome difficulties "together with honest Croats and Slovenians," and survive despite "the desperate times we live in" (Jutro 1928: 1).

A disguised critique was expressed in Slovenec as well as in Slovenski narod. In June of 1922 newspapers were full of detailed reports of the king's wedding. His marriage to 
a Romanian princess was warmly welcomed in liberal newspapers, but only Slovenec, an opponent of the constitution, was very cut-and-dry, writing that the wedding would contribute only to his happiness and "assure succession to the throne, at least while we have a monarchy" (Slovenec 1922: 1).

On the seventh anniversary of Unification Day, Slovenski narod wrote that it was indeed the most important holiday we had, but we nevertheless had to develop a critical stance. It concludes that "our prosperity is yet to come," together with a new "national and cultural type of Yugoslav" in "good physical condition and mental health" (Slovenski narod 1925: 1).

Content analysis reveals that the last category has a negative sign, which means that its objects are denied. Thus there is a negation of myths of genesis and origin (we hope that unification is possible, but "common sense tells us" that "this process takes a long time"), of "Homo yugoslavicus" = a "Homo externus" (all anti-centralist parties that are against the "reactionary, centralistic" St. Vitus's Day Constitution, Serbian "vile and violent individuals," who cannot overcome difficulties and are opposed to "honest Serbs Croats and Slovenians"; a "national and cultural type of Yugoslav" in "good physical condition and mental health" does not yet exist), of the narrative of a collective political history ("we love Serbs and hold them in high esteem," but "there is no reason to despise ourselves") and of the discursive construction of the collective present and future ("thrones are shaking and falling everywhere," we will no longer "worship monarchs," "common sense tells us" that unification is a long process, although "the regent swore" on the constitution, we are "strongly against it," we demand "the revision of reactionary, centralistic constitution," the king's marriage is not our concern, the only important thing is to "assure succession to the throne, at least while we have a monarchy," we found ourselves in a "disgusting situation," "our unity" is in "serious danger," we live in "desperate times." Unification Day is very important, "but we must nevertheless develop a critical stance," "our prosperity is yet to come").

Study of these linguistic means and forms of realization shows that lexical units in the last category, which express unity, sameness, singularity, and autonomy, have a negative sign and thus express heteronomy. "We" and all its possessive forms have a negative connotation, for we are unlike the rest of the world in a negative way on the one hand and we are different from our king on the other (we are surrounded only "by republics," we will no longer "worship monarchs," we are "strongly against" the constitution, "it is against our will," the marriage will "contribute only to his happiness,"10 "succession to the throne" is assured, at least while we have a monarchy, we found ourselves in a "disgusting situation," "our unity" is in "serious danger," we live in "desperate times," "our prosperity is yet to come").

Metonymies ("monarchs are believed to be "earthly gods," "thrones are shaking and falling," we will not "grovel before them," "common sense tells us" that unification is very unlikely to happen, we found ourselves in a "disgusting situation," "vile and violent

10 And not to our own! 
individuals" in Serbia, we live in "desperate times") and synecdoches (revision of the constitution will be "a motto of every anti-centralistic party," only an "honest Serbian nation will be able" to overcome difficulties, we need a new "national and cultural type of Yugoslav" in "good physical condition and mental health") are also not in favor of the regime and sometimes create a pejorative meaning.

\section{CONCLUSION}

These seven categories contain all three interrelated dimensions of a discursive construction of national identity: contents, strategies, and linguistic means and forms of realization. Contents are present in myths of genesis and origin, expression of sameness through difference/identity per negationem, the Alexander among the Slovenian people/identificational category, poems, Alexander as a hero/celebrity and-with a negative connotation-in an outspoken and disguised critique of the regime. Strategies (the "we" group and marginalization of "other") are used in all categories, except in outspoken and disguised critiques of the regime, whereby "we" and all its possessive forms have a negative connotation, and in anecdotes, where they are not used at all. Linguistic means and forms of realization are, naturally, present in all categories.

After unification, his position was consolidated mostly through myths of genesis and origin and related contents, the idea of "a Homo yugoslavicus," "a Homo externus" and a discursive construction of collective present and future. Slovenians welcomed their new "national" king, determined that from now on they had nothing in common with "Fritzes" and must thus unite with the victorious Serbs, whose example must be followed in all respects. Linguistic means and forms of realization express Yugoslav unity, sameness, singularity, autonomy, and heteronomy in the past; "we" forms, metonymies, synecdoches, and sometimes personifications are used to express identification with the king.

When Regent Alexander visited Slovenia for the first time in 1920, newspapers contained the idea of "a Homo yugoslavicus," "a Homo externus," and the discursive construction of collective present and future. His position was consolidated only directly, using "we" forms, metonymies, and synecdoches, which enabled the nation's identification with the king. Anecdotes about him appeared in Slovenian newspapers before his first arrival in the Slovenian part of the kingdom and later before the days of national importance and before his national and also personal achievements. Their intention was to show Alexander's humanity; giving different examples from his life, they indirectly consolidated his reign. The most important linguistic means and forms of realization are metonymies, which show him in a different light: as a mysterious, modest guest, a brave, unselfish soldier, and a godfather.

When Alexander became king in 1921, newspapers began to write about his heroic qualities and thus created a celebrity. His position was consolidated directly, using the discursive construction of the collective present and future and lexical units that express 
unity, sameness, singularity, and autonomy. "We" groups, metonymies, synecdoches and personification are used to express the deepest love and admiration for the king, especially after his assassination. After 1929, when he introduced the personal dictatorship and newspapers were censored, the people all remembered his achievements on anniversaries of Unification Day and on his birthday. After his death, his life was described in the youth magazine Sokolič according to Campbell's later monomyth.

Critique of the regime had been hardly ever present in the liberal Slovenski narod and Jutro, whereas in conservative Slovenec outspoken critique had appeared very early; in fact, the day after unification. It appeared again in 1921, when Slovenec was appalled that the St. Vitus's Day Constitution was adopted, using discursive construction of the collective present and future. In the following years its critique was more or less disguised; for example, on the day of the king's wedding, when Slovenec expressed its disapproval of the regime in a sophisticated manner. Although the liberal Slovenski narod and Jutro were in favor of the regime, in the mid-1920s there nevertheless appeared disguised and later (when Stjepan Radić was shot) outspoken criticism. The conservative Slovenec, on the other hand, never tried to hide its disapproval of the regime and therefore sometimes ignored Unification Day anniversaries and once wrote that St. Vitus's Day had little importance. However, when Anton Korošec became prime minister in 1928, its point of view naturally changed. In this category lexical units express heteronomy, for "we" were, unlike the rest of the world, not free; "we" and all its possessive forms have a negative connotation, whereas metonymies and synecdoches sometimes create a pejorative meaning.

After the January 6th Dictatorship expressing a critical attitude towards the regime was forbidden, and so, when analyzing and comparing newspapers of the time, one must "rediscover the silent murmuring, the inexhaustible speech that animates from within the voice that one hears, re-establish the tiny, invisible text that runs between and sometimes collides with them." (Foucault 2001: 31). Comparing three leading newspapers, I discovered that-despite the censorship-disguised critique was still present in Slovenec, owned by the Slovenian People's Party, whose leader Korošec was not on good terms with the royal regime. It is true that due to censorship anniversaries of Unification Day and the king's birthday made the front pages of all newspapers, but, if one reads Slovenec carefully, one discovers that within the panegyric under the large photograph of him are lines about the "homeless Slovenians" that were still living in Austria and Italy.

As the regent and leader of the victorious Serbian nation, through whose veins ran our blood, Alexander became our first "national" king in 1921. His position in the newspapers was consolidated directly and indirectly, through text and speech by himself and others, especially in the liberal Slovenski narod and Jutro, whereas Slovenec took a critical stance towards his regime several times. When he became king, Slovenian liberal newspapers started writing about his heroic qualities, whereas Slovenec was much more formal and cut-and-dry.

When his real achievements were overshadowed by his appearance in the newspapers, he, adopting Boorstin's definition, became a celebrity and was thereby destroyed by the 
publicity, which, in a way, had made him. The real man was replaced by his image in the newspapers, which means that his real existence depended on the media. The period of his dictatorship coincided with changes in the newspapers, by which I mean that his photographs replaced or at least overshadowed the details of his life, as, for instance, on the anniversaries of Unification Day and on his birthday. In postwar Yugoslavia newspapers no longer wrote about the man, who had once been considered "our king Matthias," and "the man-leader-nation"—our first "national" king—was forgotten for a long time.

\section{SOURCES}

Aleksander. 1918. Proklamacija ujedinjenja s Srbijo. Slovenski narod (December 3rd): 1.

Aleksander. 1929. Mojemu dragemu narodu! Vsem Srbom, Hrvatom in Slovencem! Slovenskinarod(January 7th): 1. Funtek, Anton. 1920. Prestolonasledniku regentu Aleksandru. Slovenski narod (June 27th): 1.

Jutro. 1923. Ljubljana, 6. septembra. (September 7th): 1.

Jutro. 1928. Ljubljana, 27. junija. (June 28th): 1.

Jutro. 1931. 3. september. (September 4th): 2.

Jutro. 1934. Kralj je mrtev. Živel kralj! (October 10th): 2.

Leskovec, Janko. 1918. Srbi in mi. Slovenski narod (December 17th): 1.

M. P. 1918. Kratek pregled zgodovine Slovencev, Hrvatov in Srbov. Slovenski gospodar (December 24th): 2. Slovenski narod. 1925. Ob obletnici ujedinjenja (Naše nacionalne bilance). (December 1st): 1.

Slovenec. 1918.Monarhija ali republika, centralizem ali avtonomija. 1918. Slovenec (December 2nd): 1.

Slovenec. 1920. Triumfalni sprejem regenta v Sloveniji. 1920. Slovenec (June 27th): 1.

Slovenec. 1921. Za revizijo ustave. 1921. Slovenec (July 1st): 1.

Slovenec. 1922. Država Srbov, Hrvatov in Slovencev. 1922. Slovenec (June 8th): 1.

Slovenski gospodar. 1918. Praznik narodnega ujedinjenja v Mariboru. (December 19th): 1.

Slovenski gospodar. 1918. Savinjska. Naša trobojnica. (December 24th): 2.

Slovenski gospodar. 1918a.Mi in Srbi. 1918a. Slovenski gospodar (December 12th): 1.

Slovenski narod. 1918. Misli o svobodi. 1918. Slovenski narod (December 13th): 1.

Slovenski narod. 1919. Vidov dan. 1919. Slovenski narod (June 7th): 1.

Slovenski narod. 1920a. Kraljevič Aleksander o svojem bivanju v Sloveniji. 1920a. Slovenski narod (July 1st): 1.

Slovenski narod. 1920b. Kraljevič Aleksander prvič na Slovenskem. 1920b. Slovenski narod (June 27th): 3.

Slovenski narod. 1920c. Prestolonaslednik regent Aleksander v Ljubljani. 1920c. Slovenskinarod (June 27th): 2 .

Slovenski narod. 1921a. Človek lahko pripada. 1921a. Slovenski narod (August 21st): 3.

Slovenski narod. 1921b. Prestolonaslednik bo zadnji! (August 21st): 2.

Slovenski narod. 1921c. Šišano kumstvo. 1921c. Slovenski narod (August 21st): 3. 
Slovenski narod. 1934. Slovo stalnega prošta Nadraha. (October 18th): 3.

Sokolič. 1934. Kljć. Veličina dela iživota Viteškog Kralja Aleksandra I. Ujedinitelja. Sokolič (Oktober): 280-282. Župančič, Oton. 1934. Žara s slovensko prstjo. Slovenec (October 18th): 3.

\section{REFERENCES}

Amon, Smilja. 1996. Tisk in politika v Jugoslaviji (1918-1941). Ljubljana: Fakulteta za družbene vede.

Anderson, Benedict. 2006. Imagined Communities. London: Verso.

Boorstin J., Daniel. 1992. The Image. A Guide to Pseudo-Events in America. New York: Vintage Books.

Campbell, Joseph. 2004. The Hero with a Thousand Faces. Princeton, NJ: Princeton University Press.

de Cillia, Rudolf, Martin Reisigl, \& Ruth Wodak. 1999. The Discursive Construction of National Identities. Discourse \& Society 10(149): 149-173.

Foucault, Michel. 2001. Arheologija vednosti. Transl. Uroš Grilc. Ljubljana: Studia humanitatis.

Gašparič, Jure. 2010. Cenzura v času diktature kralja Aleksandra. In Mateja Režek (ed.), Cenzurirano: zgodovina cenzure na Slovenskem od 19. stoletja do danes, pp. 89-98. Ljubljana: Nova revija.

Hobsbawm, Eric. 1998. Inventing Traditions. In: Eric Hobsbawm \& Terence Ranger (eds.), The Invention of Tradition, pp. 1-14. Cambridge: Cambridge University Press.

Jezernik, Božidar. 2013a. Politika praznovanja. In Božidar Jezernik (ed.), Politika praznovanja: prazniki in oblikovanje skupnosti na Slovenskem, pp. 7-16. Ljubljana: Znanstvena založba Filozofske fakultete.

Jezernik, Božidar. 2013b. Temeljni kamen kot kamen spotike. In Božidar Jezernik (ed.), Politika praznovanja: prazniki in oblikovanjeskupnosti na Slovenskem, pp. 17-46. Ljubljana:Znanstvena založba Filozofske fakultete.

Nežmah, Bernard. 2012. Časopisna zgodovina novinarstva na Slovenskem med letoma 1797-1989. Ljubljana: Študentska založba.

Polajnar, Janez, \& Marko Zajc. 2012. Naši in Vaši: iz zgodovine slovenskega časopisnega diskurza v 19. in začetku 20. stoletja. Ljubljana: Mirovni inštitut. 


\section{JUGOSLOVANSKI KRALJ ALEKSANDER I. KARAĐORĐEVIĆ IN METAMORFOZE NJEGOVE PODOBE V SLOVENSKEM ČASOPISJU}

Članek predstavi, kako so osrednji slovenski časopisi dojemali in prikazovali jugoslovanskega kralja Aleksandra I. Karađordevića. Avtorica analizira, kako se je njegova medijska podoba spremenila v obdobju njegovega vladanja, in sicer od leta 1918, ko je postal regent, ter tri leta zatem kralj Kraljevine Srbov, Hrvatov in Slovencev, do uvedbe diktature leta 1929 in atentata $v$ Marseillu leta 1934. Članek se osredotoča na prevladujoč diskurz v medijskih poročilih o pomembnih prelomnicah in dogodkih, ki so imeli velik javni in nacionalni pomen, kot so ustanovitev kraljevine, volitve in prazniki, kraljeva poroka in rojstvo otrok. V medijih je odmeval še atentat na hrvaškega politika Stjepana Radića, uvedba šestojanuarske diktature ter seveda umor kralja leta 1934. Ob takšnih prilikah so mediji pomen Aleksandra I. Karadordevića vsakič znova opisali, razložili in utemeljili; niso pa ga prikazovali le kot vojnega junaka in velikega človeka, temveč tudi kot slavno osebnost. Članek s takšnimi primeri razloži razumevanje naroda kot zamišljene skupnosti ter njenih imaginarnih tradicij in praznikov in pokaže, kako so to predstavili dnevnih časopisi, in sicer najprej v Kraljevini Srbov, Hrvatov in Slovencev in kasneje še v Kraljevini Jugoslaviji.

Sara Špelec, Department of Ethnology and Cultural Anthropology, Faculty of Arts, University Ljubljana, Zavetiška 5, SI-1000 Ljubljana 